The genus Sida has $150-200$ species distributed widely in tropical and subtropical regions of the world (Willis 1973). Eighteen species are known to occur in India (Sivarajan \& Pradeep 1994). Nine OPEN ACCESS species of Sida occur in Tamil Nadu, along with two subspecies (Daniel \& Umamaheshwari 2001). S. fryxellii Sivar. \& Pradeep is endemic to Kerala (Sivarajan \& Pradeep 1990). Sida ravii Sivad. \& Anil Kumar is endemic to peninsular India (Sivadasan \& Kumar 1996).

The genus Sida consists of annual or perennial herbs or undershrubs with axillary flowers either solitary, or in clusters by the development of axillary buds or raceme or panicles by replacement of the upper leaves. Epicalyx is absent. Corolla is rotate, connate below and adnate to the staminal column. Staminal column is shorter than the petals. Carpels are 5-14, uniovolate. Fruits are schizocarps, globular to oblate and depressed. Mericarps are more or less trigonous, muticous or with the two awns at apex. Seeds are ovoid-oblong to reniform.

Sida spp. also show a wide range of morphological variability (Fryxell 1978 \& 1985). The characters of Sida ravii showed close relationship to Sida acuta Burm.f. and Sida spinosa L. (Table 1). Fryxell $(1985,1988,1997)$ revised Indian Malvaceae which is followed in the revised

\section{SIDA RAVII Sivad. \& ANIL KumAR (MAlVACEAE) A NEW RECORD FROM TAMILNADU, INDIA}

\author{
N. Dhatchanamoorthy ${ }^{1}$, P. Raja ${ }^{2}$, S. Soosairaj ${ }^{3}$ \&
}

A. Kala ${ }^{4}$

\author{
${ }^{1,2,4}$ Research Scholar, ${ }^{3}$ Assistant Professor, \\ Department of Botany, St. Joseph's College, Tiruchirappalli, \\ Tamil Nadu 620002, India
}

${ }^{1}$ dhatcha@gmail.com, ${ }^{2}$ raja.plantbiology@gmail.com, ${ }^{3}$ pspsoosai@yahoo.in (corresponding author), ${ }^{4}$ akalabot7@yahoo.in

Flora of India (Paul 1993). Sivarajan \& Pradeep (1994) stated that the genus Sida was a difficult group and several authors had attempted sub-generic classification of the genus. Based on the number of carpels and seeds per carpel, De Candolle (1824) recognized three sections in Sida, namely, Malvinda Medik. Abutiloides Kunth. \& Medik. and Abutilon Kunth.

Pachchaimalai is situated in Tiruchirapalli District in the southern Eastern Ghats of Tamil Nadu and lies between $11^{\circ} 16^{\prime} 28.320^{\prime \prime} \mathrm{N} \& 78^{0} 38^{\prime} 02.742^{\prime \prime} \mathrm{E}$. The Pachchaimalai Hills with altitude ranging from 700-1200 $m$ shows a subtropical climate with temperatures varying from $25-31{ }^{\circ} \mathrm{C}$ and the annual rainfall ranging from 800 $900 \mathrm{~mm}$. The Pachchaimalai is floristically rich by virtue of its geographical location, varied forest types, different bio-climatic features, soil and topography. Pachchaimalai
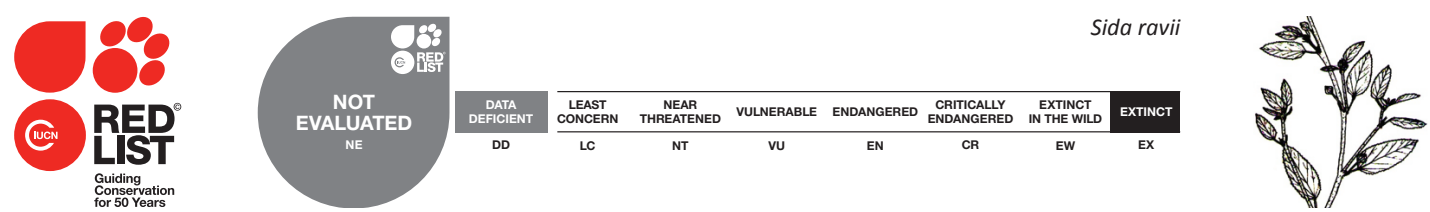

DOI: http://dx.doi.org/10.11609/JoTT.03581.7716-9

Editor: N.P. Balakrishnan, Retd. Joint Director, BSI, Coimbatore, India.

Date of publication: 26 August 2015 (online \& print)

Manuscript details: Ms \# 03581 | Received 11 April 2013 | Final received 11 June 2015 | Finally accepted 08 August 2015

Citation: Dhatchanamoorthy, N., P. Raja, S. Soosairaj \& A. Kala (2015). Sida ravii Sivad. \& Anil Kumar (Malvaceae) a new record from Tamilnadu, India. Journal of Threatened Taxa 7(10): 7716-7719; http://dx.doi.org/10.11609/JoTT.03581.7716-9

Copyright: (C) Dhatchanamoorthy et al. 2015. Creative Commons Attribution 4.0 International License. JoTT allows unrestricted use of this article in any medium, reproduction and distribution by providing adequate credit to the authors and the source of publication.

Funding: None.

Competing interests: The authors declare no competing interests.

Acknowledgements: The authors are thankful to the Director, Botanical Survey of India, Southern Regional Centre, Coimbatore for providing facilities and support. We also thank the forest officials of Tiruchchirappalli District. 
is rich in vegetation and also socio-religiously important and approximately 350 ethnobotanical medicinal plants used by indigenous people are present here.

During field exploration (2012-2014) at Pachchaimalai, the authors collected specimens of an interesting species of Sida. A critical examination of the specimens revealed its identity as Sida ravii. The identity of the species was further confirmed with published literature (Fryxell 1978). This species has so far not been collected from Tamil Nadu. Hence, the present collection is the first report and is an addition to the flora of Tamil Nadu. Voucher specimens are deposited at the Department herbarium, St. Joseph's College, Tiruchirappalli. A detailed description, nomenclature and other relevant information are provided for the easy identification of Sida ravii and a table of differentiation from the close resembling species $S$. acuta, and $S$. spinosa.

\section{Sida ravii}

Sivad. \& Anil Kumar, Willdenowia 25: 651. 1996.

Erect, profusely branched undershrubs, up to $1.5 \mathrm{~m}$ high; branchlets subterete, stellate-hairy. Leaves alternate, ovate-lanceolate, oblong-elliptic or lanceolate, 2-7 x 1-4 cm, cordate-rounded at base, crenate, serrate at margin, acute at apex, sparsely stellate-pubescent or glabrescent; 6-8 pair of main lateral nerves, basally 5-nerved at base. Petioles terete, 5-15 mm long, slightly thickened below. Stipules 2, linear, 5-7 mm long. Flowers axillary, 1-3 flowered; pedicel erect, terete, bent upwards, 1-3 cm long.
Calyx 5-lobed, campanulate, articulate near calyx base; lobe deltoid, ca. $5 \mathrm{~mm}$ long, acuminate at apex, faintly 10-nerved, glabrous inside. Corolla 5-lobed, rotate, 15-20 cm across; petals 5, obliquely obovate, 10-12 $\mathrm{mm}$ long, shallowly emarginated at apex, simple hairy. Staminal tube cylindrical, 3-4.2 $\mathrm{mm}$ long; filament filiform, ca. $1.5 \mathrm{~mm}$ long, glabrous. Ovary ovoid, ca. $2 \mathrm{~mm}$ long; 5-loculed; ovules two per cell; style filiform, 2-3.5 mm long, glabrous; stigma capitate. Schizocarp subglobose, ca. $7 \mathrm{~mm}$ long; mericarps $8-10$ or 12 , radially compressed, reticulately ribbed beneath, divergent, mucronate at apex, glabrous or stellate-hairy; seeds 1-2 per cell, subreniform, $1.5 \mathrm{~mm}$ long, glabrous, brownishblack (Fig. 1).

Specimens examined: SJCBOT1218, 19.xi.2012, Tiruchirappalli District: On way to Ramanathapuram from Turaiyur (Pachchaimalai), 759m, coll. S. Soosairaj (Fig. 2; Image 1).

Flowering \& Fruiting: July-December.

Habitat: Rare, along roadsides and cultivated lands, at about $750 \mathrm{~m}$ altitude. Found associated with Senna tora, Sida acuta, Sida cordifolia, Solanum americanum and Vernonia anthelmintica.

Distribution: India; Kerala and Tamil Nadu (Pachchaimalai)

Remarks: In India, Sida ravii is reported to occur in the Western Ghats, Kerala (Kumar et al. 2005). However, there are no authentic specimens from any of the southern states in the Madras Herbarium (MH) and it is not reported in any of the floras pertaining to the Western Ghats and Eastern Ghats (Haines 1924;

Table 1. Species that is closely related to Sida acuta and Sida spinosa

\begin{tabular}{|c|c|c|c|}
\hline & Sida ravii Sivad. \& Anil Kumar & Sida acuta Burm.f. & Sida spinosa L. \\
\hline 1 & Undershrub, up to $1.5 \mathrm{~m}$ high & Undershrub, up to $70 \mathrm{~cm}$ high & Spiny undershrub, up to $1 \mathrm{~m}$ high \\
\hline 2 & $\begin{array}{l}\text { Leaves ovate-lanceolate, oblong-elliptic or } \\
\text { lanceolate, serrate at margin }\end{array}$ & $\begin{array}{l}\text { Lower leaves rhomboid-elliptic and upper } \\
\text { leaves, linear to lanceolate, coarsely remotely } \\
\text { serrate at margin }\end{array}$ & $\begin{array}{l}\text { Leaves oblong-elliptic or obovate, serrate at } \\
\text { margin }\end{array}$ \\
\hline 3 & Petioles $5-15 \mathrm{~mm}$ long & Petioles 2-6 mm long, minute stellate hairy & Petioles 2-25 mm long, glabrescent \\
\hline 4 & Stipules 2, linear, 5-7 mm long & Stipules linear-filiform, 2-12 mm long & Stipules linear, 1-2.5 mm long \\
\hline 5 & Flowers solitary, 1-3 in axillary node & Flowers solitary $2-3$ in axillary node & Flowers solitary, $2-5$ in axillary node \\
\hline 6 & Pedicel erect, bent upwards, $1-3 \mathrm{~cm}$ long & Pedicel 3-12 mm long pubescent & Pedicel 2-8 mm long \\
\hline 7 & Calyx $5 \mathrm{~mm}$ across, accrescent & $\begin{array}{l}\text { Calyx 5-6 } \mathrm{mm} \text { across campanulate slightly } \\
\text { accrescent }\end{array}$ & Calyx 3-5 mm across, campanulate \\
\hline 8 & $\begin{array}{l}\text { Corolla } 15-20 \mathrm{~cm} \text { across, petals as equal as the } \\
\text { calyx lobe }\end{array}$ & $\begin{array}{l}\text { Corolla } 8-10 \mathrm{~mm} \text { across; petals as long as the } \\
\text { calyx lobes }\end{array}$ & Corolla $5-8 \mathrm{~mm}$ across \\
\hline 9 & Staminal column 3-4.2 mm long & Staminal column ca. $4 \mathrm{~mm}$ long, glandular hairy & Staminal column 2-2.6 mm long, glabrous \\
\hline 10 & $\begin{array}{l}\text { Mericarps } 8-10 \text { or } 12 \text {, radially, } 3-5 \mathrm{~mm} \text { long, } \\
\text { compressed, with } 2 \text { awns at apex }\end{array}$ & $\begin{array}{l}\text { Mericarps } 4-10 \mathrm{ca} .4 \mathrm{~mm} \text { long, as long as the } \\
\text { calyx, with } 2 \text { awns at apex } 1.5 \mathrm{~mm} \text { long }\end{array}$ & $\begin{array}{l}\text { Mericarps } 5 \text {, trigonous, } 2-3 \mathrm{~mm} \text { long, with } 2 \\
\text { awns at apex, } 1.5 \mathrm{~mm} \text { long }\end{array}$ \\
\hline 11 & $\begin{array}{l}\text { Seeds subreniform, } 1.5 \mathrm{~mm} \text { long, glabrous, } \\
\text { brownish-black. }\end{array}$ & $\begin{array}{l}\text { Seeds ovoid, ca. } 2 \mathrm{~mm} \text { long dark brown, } \\
\text { glabrous except for the short hairs }\end{array}$ & $\begin{array}{l}\text { Seeds ovoid, } 1.5 \mathrm{~mm} \text { long, glabrescent, } \\
\text { brownish black }\end{array}$ \\
\hline
\end{tabular}




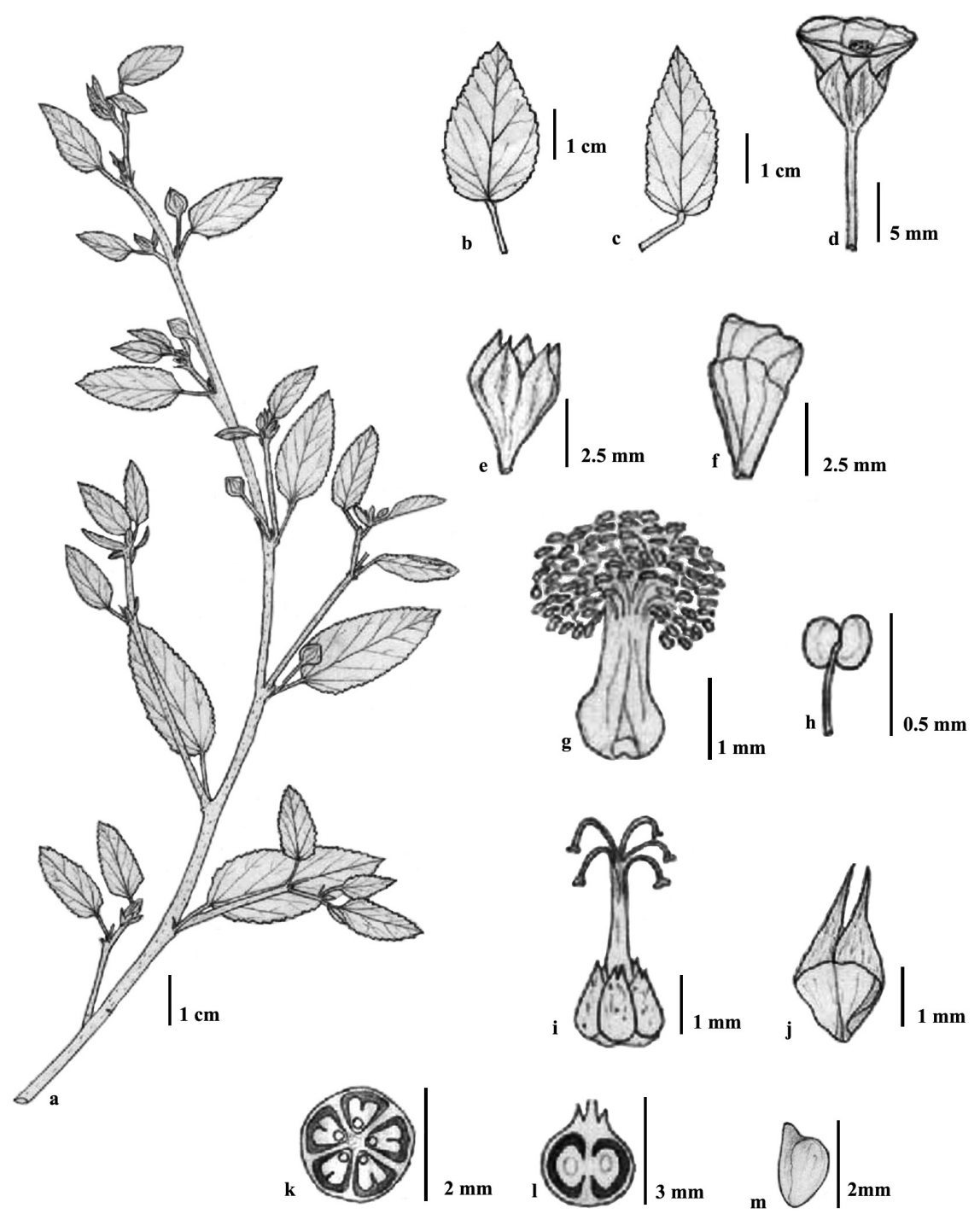

Figure 1. Sida ravii. a - Habit; b\&c - Leaf; $\mathrm{d}$ - Flower; e - Calyx; f - Coralla; g - Staminal Column; h - Stamen; i - Pistil; j\&k - Ovary t.s \& I.s; I - Mericarp; $\mathrm{m}$ - Seed

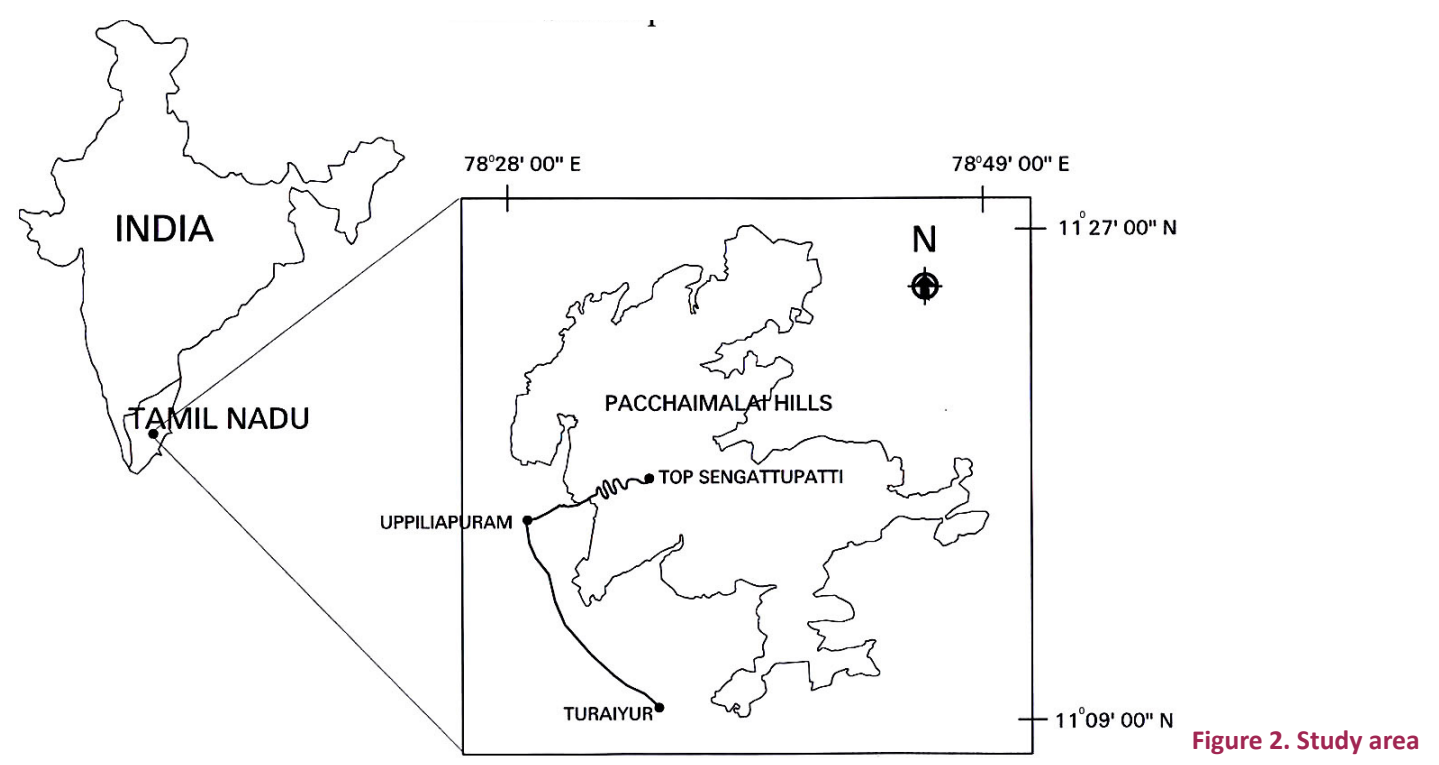




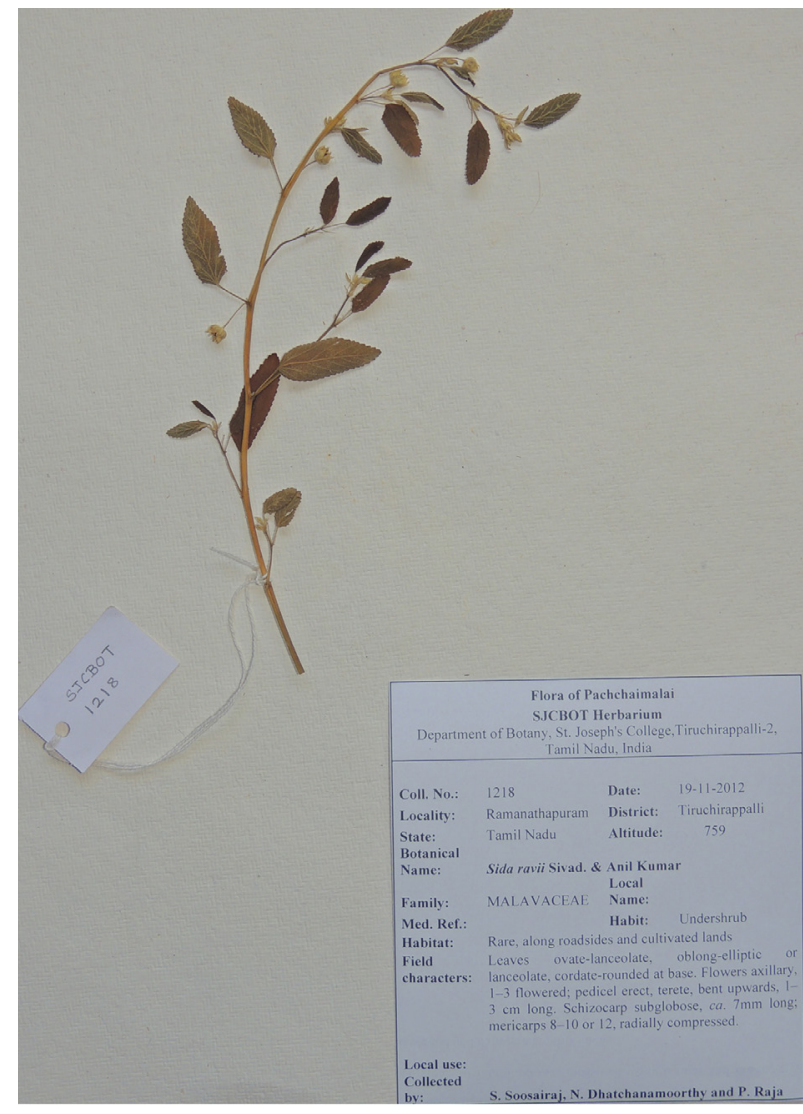

Image 1. Herbarium of Sida ravii

Fyson 1932; Mooney 1950; Gamble 1957; Narasimhan 1991; Matthew 1983, 1999; Pullaiah \& Moulali 1997; Pallithanam 2001; Manickam et al. 2003; Murugesan 2006; Nayar et al. 2006; Pullaiah \& Karuppusamy 2008). We found Sida ravii to be rarely distributed in the Eastern Ghats of Tamil Nadu. Probably it is spread from Kerala State as the Tapioca stem cuttings are purchased for cultivation.

\section{References}

Daniel, P. \& P. Umamaheswari (2001). The Flora of the Gulf of Mannar, southern India. Botanical Survey of India, 81.

De Candolle, A. (1824). Prodromus Systematis Naturalis Regni Vegetabilis - Vol. 1. Treuttel \& Wiirtz rtz, Paris, 748pp.

Fyson, P.F. (1932). The Flora of the South Indian Hill Stations. Vol. I \& II. Madras, 697pp \& 611pp.

Fryxell, P.A. (1985). Four new species of Malvaceae from Venezuela. Systematic Botany 10: 273-281.

Fryxell, P.A. (1988). Batesimalva, pp. 129-131. In: Malvaceae of Mexico. Systematic Botany Monograph 25: 1-588.

Fryxell, P.A. (1978). Neotropical Segregates from Sida L. (Malvaceae). Brittonia 30: 447-462.

Fryxell, P.A. (1997). The American Genera of Malvaceae - II. Brittonia 49: 204-269.

Gamble, J.S. (1957). Flora of Presidency of Madras. Vol. 1-3. Reprint edition. Calcutta, 1389pp.

Manickam, V.S., G. J. Jothi, C. Murugan \& V. Sundaresan (2003). Check-list of the Flora of Tirunelveli Hills, Southern Western Ghats, India. St. Xavier's College, Palayamkottai, Tamil Nadu, India, 200pp.

Matthew, K.M. (1983). The Flora of the Tamilnadu Carnatic - Vol. 1-3. The Rapinat Herbarium, Tiruchirapalli, 2152pp.

Matthew, K.M. (1999). Flora of the Palni Hills, South India. Volumes 1-3. The Rapinat Herbarium, Tiruchirapalli, 1880pp.

Mooney, H.F. (1950). Supplement to the Botany of Bihar and Orissa. International Book Distributors, Dehradun, 274pp.

Murugesan, M. (2006). Floristic diversity and ethnobotanical studies in Vellingiri Hills, The Western Ghats of Coimbatore District, Tamil Nadu, India. PhD Thesis. Bharathiar University.

Narasimhan, D. (1991). Systematic studies on the Flora of Chengalpattu District, Tamil Nadu, India. PhD Thesis. Madras University, Chennai.

Nayar, T.S., A.R. Beegam, N. Mohanan, G. Rajkumar \& M. Sibi (2006). Flowering Plants of Kerala - A Handbook. TBGRI, Thiruvananthapuram, Kerala, 1069pp.

Pallithanam, J.P. (2001). A Pocket Flora of the Sirumalai Hills, South India. The Rapinat Herbarium, Tiruchirapalli, 360pp.

Paul, T.K. (1993). Malvaceae, pp. 257-394. In: Sharma, B.D., M. Sanjappa \& N.P. Balakrishnan (eds.). Flora of India - Vol. 3. Botanical Survey of India, Calcutta.

Pullaiah, T. \& D.A.A. Moulali (1997). Flora of Andhra Pradesh - Vol. 2. Scientific Publisher, Jodhpur.

Pullaiah, T. \& S. Karuppusamy (2008). Flora of Andhra PradeshAdditions, Floristic Analysis and Further Illustrations - Vol. V. Scientific Publisher, Jodhpur, India.

Sivadasan, M. \& N.A. Kumar (1996). Sida ravii, a new species of Malvaceae from India. Willdenowia 25(2): 651-654.

Sivarajan, V.V. \& A.K. Pradeep (1990). Sida fryxellii, a new species of Malvaceae from Peninsular India. Kew Bulletin 45: 725-727.

Sivarajan, V.V. \& A.K. Pradeep (1994). Malvaceae of Southern Peninsular India: A Taxonomic Monograph. Daya Publishing House, Delhi, 312pp.

Willis, J.C. (1973). A Dictionary of the Flowering Plants and Ferns (Eighth Edition). University Printing Press, Cambridge, 1333. 